\title{
EOlǴTIOด volume 38, 2013 química \\ STUDY OF THE CATALYTIC ACTIVITY OF BOVINE BONE POWDER IMPREGNATED WITH FE(III) NEW MATERIAL FOR THE CATALYTIC DEGRADATION OF INDIGO CARMINE
} Artigo/Article

Márcio G. Coelho ${ }^{\mathrm{a}^{*}}$, Geraldo M. de Lima ${ }^{\mathrm{a}}$, Rodinei Augusti ${ }^{\mathrm{a}}$, José D. Ardisson ${ }^{\mathrm{b}}$, Fabrício V. de Andrade $^{\mathrm{a}}$ and Luciana S. Duarte ${ }^{\mathrm{a}}$.

${ }^{a}$ Departamento de Química, ICEx, Universidade Federal de Minas Gerais, 31270-901 Belo Horizonte, MG, Brazil, *E-mail address:proquimarcio@gmail.com, Tel.: $55313409574{ }^{b}$ Centro de Desenvolvimento em Tecnologia Nuclear, CDTN, 31270 901, Belo Horizonte, MG, Brazil

\begin{abstract}
In this work, a composite consisting of bovine bone powder impregnated with $\mathrm{Fe}(\mathrm{III})$ ions was prepared and its performance evaluated as a catalyst for the degradation of the textile dye Indigo Carmine in aqueous medium. One of the advantageous features of this new material is that it is inexpensive, simple to prepare and the support, bovine bone, is one the final residue of food production. The material was fully characterized by X-ray powder diffraction (DRX), ${ }^{57} \mathrm{Fe}-\mathrm{Mössbauer}$ spectroscopy, surface area measurements (BET), atomic absorption spectrometry. The degradation of Indigo Carmine was monitored by ultraviolet spectroscopy in the visible region (UV-Vis) and the by-products characterized by direct infusion ESI(-)MS (electrospray ionization mass spectrometry in the negative ion mode).
\end{abstract}

Keywords: Photocatalysis, wastewater, indigo Carmine, bovine bone.

\section{Resumo}

Neste trabalho, um composto constituído de pó de osso bovino impregnado com Fe(III) foi preparado e seu desempenho como um catalisador para a degradação do corante têxtil Índigo Carmim em meio aquoso foi avaliado. Uma das características vantajosas deste novo material é que é barato, simples de preparar e o suporte, osso bovino, é um resíduo final da produção de alimentos. O material foi totalmente caracterizado por difração de raios-X de pó (DRX), espectroscopia Mössbauer de ${ }^{57} \mathrm{Fe}$, medidas de área superficial (BET), espectrometria de absorção atômica. A degradação do Índigo Carmim foi monitorada por espectroscopia de ultravioleta na região do visível (UV-Vis) e os subprodutos caracterizadas por ESI(-)MS (espectrometria de massas com fonte de ionização por eletrospray no modo negativo) através do método de infusão direta.

Palavras-chave: Fotocatálise, águas residuárias, índigo carmim, osso bovino 


\section{Introduction}

According to tests performed by the Ecological and Toxicological Association of the Dyestuffs Manufacturing Industry (ETAD) more than 90\% of the 4,000 dyes normally used in industrial processes show some level of toxicity [1-3]. In the international market of dyes and pigments, about $50 \%$ corresponds to azo-based materials, $\mathrm{R}-\mathrm{N}=\mathrm{N}-$ $\mathrm{R}^{\prime}$ [4].

Several studies have linked azo pigments with basal cell carcinoma [5, 6], and some of their degradation products are even more toxic [7]. Their industrial wastewaters are also reason for concern, because of toxicological and environmental effects on a number of microorganisms and colour pollution [8]. Regarding the former, very small quantities of dyes can be easily recognized either in industrial products or in their liquid wastes [9]. The major problems are related to the drawback of important properties of dye pigments, manly high chemical and thermal stability. Although necessary for industrial applications, these properties prevent treatment of aqueous residues, even at low concentrations when common methods are either economically unfavourable and/or technically complicated [10].

Degradation of organic substrates in aqueous solution has been usually promoted by advanced oxidative processes (AOPs) [11].

In the AOPs, the extremely reactive and powerful oxidizing hydroxyl radicals, generated in situ, promote the oxidation of target organic compounds. ${ }^{12}$ Most AOPs comprise combinations of $\mathrm{UV}$ radiation and $\mathrm{H}_{2} \mathrm{O}_{2}, \mathrm{TiO}_{2}, \mathrm{O}_{3}$, ultrasonic radiation, and the Fenton reagent [12, 13]. A number of reports have described the application of AOPs to degrade dyes in aqueous solution. For instance, an innovative array composed by $\mathrm{TiO}_{2}$ immobilized on the inner surfaces of quartz pipes continuously exposed to UV source has been successfully employed to degrade several dyes [14]. Small scale experiments have shown that the $\mathrm{TiO}_{2} /$ solar radiation system demonstrates high efficiency in removing the colour from aqueous solutions of Indigo Carmine [15]. Other papers have reported that treatment with hydrogen peroxide and transition metal complexes was able not only to promote colour removal but also to cause almost complete mineralization of solutions containing a number of dyes $[16,17]$.

The studies on the degradation of dyes in aqueous solutions have usually focused on the discoloration efficiency promoted by AOPs, whereas less attention has been given to the characterization of by-products probably formed under these oxidative conditions or their toxicological properties. For instance, GC-MS was recently used to identify by-products resulting from the degradation of a few azo dyes [18, 19]. An alternative technique to be used for this purpose is electrospray ionization mass spectrometry (ESI-MS). This technique possesses the remarkable capability to gently transfer species from the condensed to the gas phase without inducing undesirable side reactions. Because of that, ESI-MS has been successfully applied in the monitoring of an increasing number of environmental methodologies [20-25].

Following our interest in the preparation and characterization of materials with technological appeal and environmental catalysis, the aim of the present work therefore war to prepare and characterize novel materials formed by the impregnation of bovine bone powder with $\mathrm{Fe}(\mathrm{III})$ ions [26-31].

The use of materials from renewable resources in chemical processes is very important, among the potential renewable energy sources highlight the bovine bone. In this work processed bovine bone powder is used as catalytic support.

Its ability to act as a catalyst for the degradation of the textile dye Indigo Carmine in aqueous medium is evaluated. Direct infusion electrospray ionization mass spectrometry is also used in an attempt to characterize the by-products probably resulting from degradation process. 


\section{Experimental details}

All chemicals were purchased from SigmaAldrich (Milwaukee, WI) and used without further purification. Doubly distilled water was used to prepare the solutions.

\subsection{Instrumentation and techniques}

Thermal preparation of the supported material was carried out in an oven in air at $100^{\circ} \mathrm{C}$. XRD patterns were collected with a Siemens D5000 instrument using a Ni-filtered $\mathrm{Cu} \mathrm{K}_{\alpha}$ radiation ( $\square=1.5418 \AA$ ) and a graphite monochromator in the diffracted beam. A scan rate of $1 \%$ min was applied to record a pattern in the $2 \square$ range of $20^{\circ}-80^{\circ}$. Silicon was used as internal standard. The ${ }^{57} \mathrm{Fe}$ Mössbauer experiments were carried out in a spectrometer CMTE model MA250 with a ${ }^{57} \mathrm{Co} / \mathrm{Rh}$ source at room temperature using $\square$ $\mathrm{Fe}^{\mathrm{o}}$ as reference. UV-Vis measurements were performed by using a Hitachi U-2010 spectrophotometer. The measurements of atomic absorption were made in a Varian atomic absorption spectrometer (AA $240 \mathrm{FS}$ ) under the following analysis conditions: wavelength $248.3 \mathrm{~nm}$, slit 02, gas flame acetylene. ESI-MS and ESI-MS/MS analyses were performed with a LCQ Fleet mass spectrometer (ThermoScientific, San Jose, CA) operating in the negative ion mode. The reaction aliquots were directly infused into the ion source at a flow rate of $20 \mu \mathrm{L} \mathrm{min}{ }^{-1}$ using a microsyringe (Hamilton Company, Reno, $\mathrm{NV}$ ) and the mass spectra obtained as an average of 50 scans, each one requiring $0.2 \mathrm{~s}$. Typical ESI conditions were as follows: heated capillary temperature $300{ }^{\circ} \mathrm{C}$; sheath gas $\left(\mathrm{N}_{2}\right)$ flow rate 20 units (ca. $0.3 \mathrm{~L} \mathrm{~min}^{-1}$ ); spray voltage $4 \mathrm{kV}$; capillary voltage $25 \mathrm{~V}$; tube lens offset voltage $25 \mathrm{~V}$.

\subsection{Preparation of the supported material}

A piece of dry bovine bone was washed and ground in a ball mill. The bone powder were immersed on an aqueous solution of $\mathrm{FeCl}_{3}(1 \mathrm{~mol}$ $\left.\mathrm{L}^{-1}\right)$. After $24 \mathrm{hs}$ of stirring, the brownish solid was removed from the solution and left on an oven at $200{ }^{\circ} \mathrm{C}$ for $1 \mathrm{~h}$, approximately rendering $\mathrm{Fe}(\mathrm{II})$ and $\mathrm{Fe}(\mathrm{III})$ oxides. The resulting material was characterized by X-ray powder diffraction (DRX), ${ }^{57} \mathrm{Fe}-M$ össbauer spectroscopy, Surface Area Measurements (BET), Atomic Absorption Spectrometry.

\section{Catalytic Experiments}

The prepared composite $(30 \mathrm{mg}$ ) was added to an aqueous solution of Indigo Carmine $(100 \mathrm{~mL} ; 30$ $\left.\square \mathrm{mol} \mathrm{L} \mathrm{L}^{-1}\right)$ to perform the photocatalytic experiments. For the experiment, after the addition of the composite the system was exposed to an ultraviolet (UV) radiation (UV lamp: Philips HPL - N 36 Watts, wavelength ranging from 200 - $400 \mathrm{~nm}$ ). Aliquots were taken at intervals of 10 or $20 \mathrm{~min}$, filtered using a $0.45 \mu \mathrm{m}$ filter (Millipore, Jaffrey, $\mathrm{NH}$ ) to eliminate solid particles and kept protected from light in a refrigerator prior to the ESI-MS and UV-Vis.

\section{Calibration curve}

Several aqueous solutions of Indigo Carmine were prepared at assorted concentrations (30, 20, 10, 7.5, 6 and $3 \square \mathrm{mol} \mathrm{L}^{-1}$ ) and their absorbance measured at $610 \mathrm{~nm}$ ( $\square$ max of the dye). The resulting plot (not shown) displayed an excellent linear relationship with $\mathrm{R}^{2}=0.999$.

\section{Results and discussion}

\subsection{Synthesis and characterization of the $\mathrm{Fe}$ (III) / bovine bone powder composite}

The impregnated bovine bone powder displays a superficial area of $4 \mathrm{~m}^{2} \mathrm{~g}^{-1}$. The atomic absorption results revealed that the amount of iron in bovine bone powder composite was $5 \%$ by weight.

Experiments of X-ray powder diffraction have been performed after the impregnation process. The diffractions patterns correspond to a quite amorphous material, since no diffractions lines were observed. 


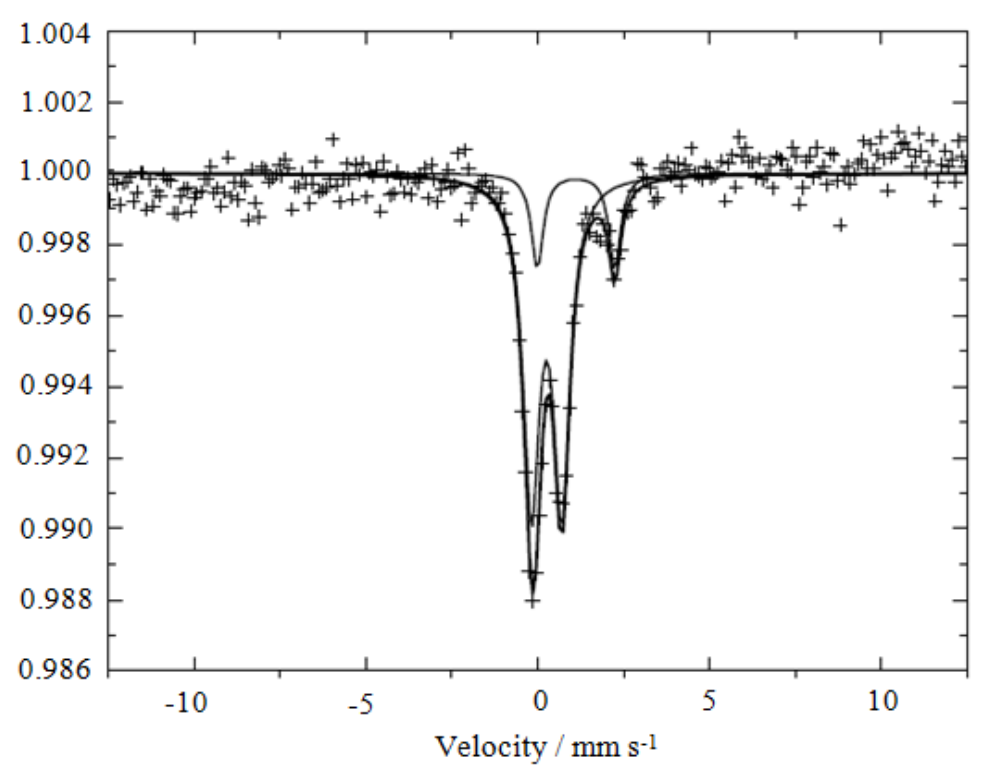

Figure 1. ${ }^{57} \mathrm{Fe}$-Mössbauer results of the $\mathrm{Fe}(\mathrm{III}) /$ bovine bone powder composite.

The ${ }^{57} \mathrm{Fe}-M o ̈ s s b a u e r$ experiments (Figure 1) served to identify the phases of iron in the samples. It was identified $\mathrm{Fe}(\mathrm{III}), 83 \%$ (isomeric deviation, $\delta=0.36 \mathrm{~mm} \mathrm{~s}^{-1}$ and quadrupolar splitting, $\mathrm{QS}=$ $\left.0.89 \mathrm{~mm} \mathrm{~s}^{-1}\right)$ and $\mathrm{Fe}(\mathrm{II}), 17 \%\left(\delta=1.12 \mathrm{~mm} \mathrm{~s}^{-1}\right.$ and $\left.\quad \mathrm{QS}=2.25 \mathrm{~mm} \mathrm{~s}^{-1}\right)$. The latter has probably resulted from a reduction of $\mathrm{Fe}(\mathrm{III})$ by collagen still present in the dry bone. This material, even dry is reach in carbon which has probably performed the reduction of $\mathrm{Fe}$ (III) to $\mathrm{Fe}(\mathrm{II})$ during heat treatment.

3.2. Degradation of the dye Indigo Carmine in aqueous solution promoted by the novel composite

\subsubsection{UV-Vis monitoring}

As Indigo Carmine has a maximum absorbance at $610 \mathrm{~nm}$, this wavelength was used to monitor the discoloration of the solution during the catalytic processes. As Figure 2 indicates, after $60 \mathrm{~min}$ of reaction the solution using ultraviolet, was completely discolored.

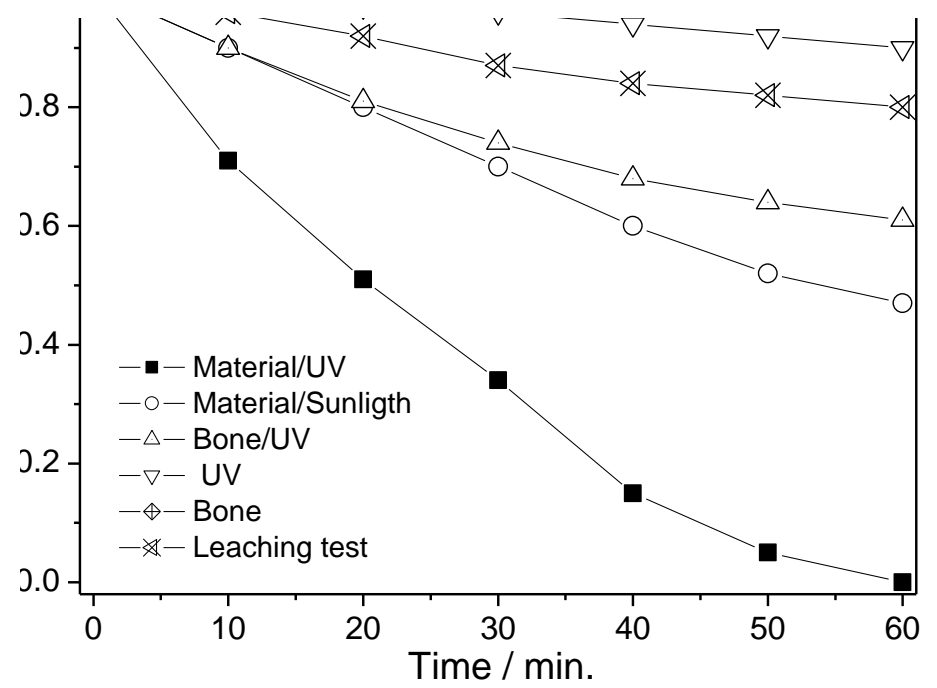

Figure 2. Monitoring degradation of the dye Indigo Carmine (at $30 \square \mathrm{mol} \mathrm{L}^{-1}$ ) in aqueous solution using sunlight and ultraviolet.

\subsubsection{ESI-MS monitoring}

Electrospray ionization mass spectrometry in the negative ion mode, ESI(-)-MS, was used to characterize the by-products formed after the degradation of Indigo Carmine in aqueous solution as promoted by the catalytic system.

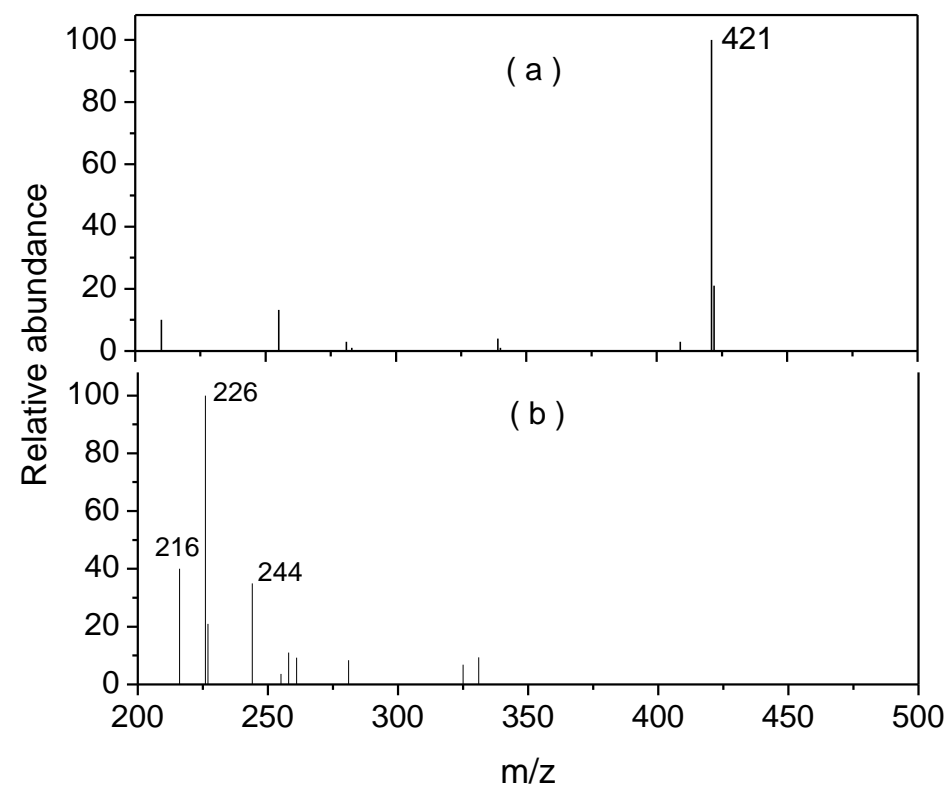

Figure 3. (a) ESI(-)-MS of the initial aqueous solution of Indigo Carmine (1) at $30 \square \mathrm{mol} \mathrm{L}^{-1}$; (b) ESI(-)-MS of an reaction aliquot withdrawn after $60 \mathrm{~min}$ of exposure to the catalytic system. 
The ESI(-)-MS of the initial aqueous solution of Indigo Carmine and of the aliquot collected after 60 minutes of exposure to the catalytic system are shown in Figures 3a and 3b, respectively. Note the presence of the anion of $m / z 421\left([1-\mathrm{H}]^{-}\right.$, the deprotonated form of Indigo Camine) in Figure 3a. In the mass spectrum of the aliquot (Figure 3b) this anion is no longer detected indicating that the dye was completely consumed. Other anions of $\mathrm{m} / \mathrm{z} 226$ (the most abundant), 244, and 216 can be observed in this mass spectrum. The mechanism of degradation of indigo carmine has been reported by other work done by our research group [31].

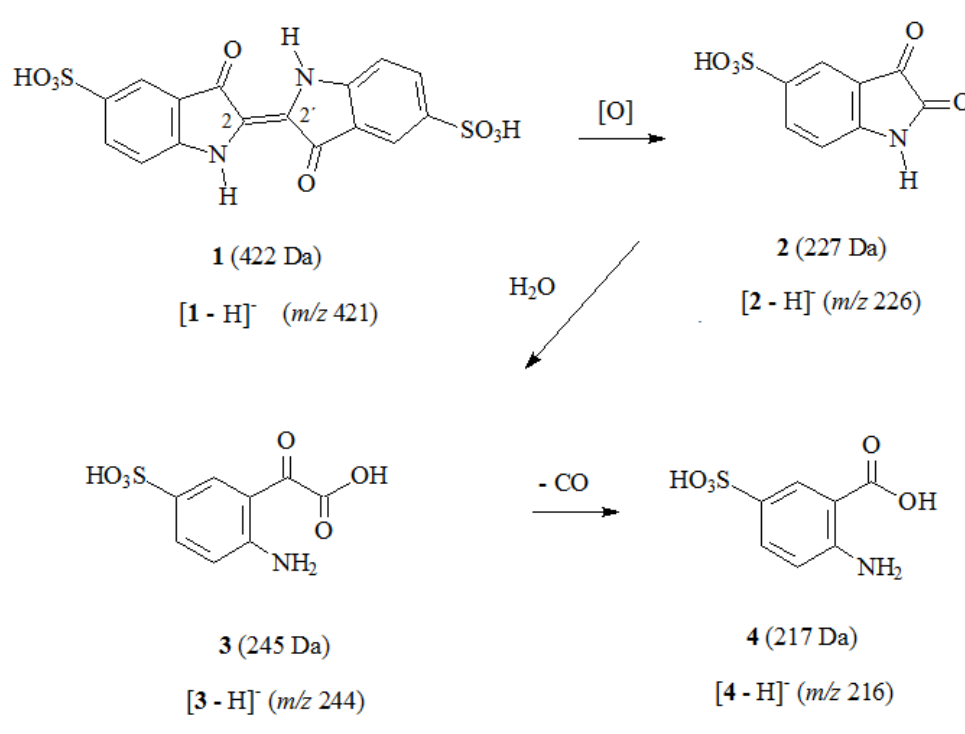

Figure 4. Proposed mechanism for the degradation of Indigo Carmine in aqueous solution promoted by the catalytic systems.

\section{Conclusions}

The composite was used as a catalyst in the photocatalytic process. The system was able to cause the complete discoloration of Indigo Carmine solutions.

According to the data obtained by ESI-MS, a mechanism for the degradation of Indigo Carmine in aqueous solution induced by system was proposed. Regardless the light source (sunlight or ultraviolet) the same sorts of products were formed thus indicating that the mechanism involved is probably the same. This is a consistent result, since it is postulated that both processes proceed via the generation of hydroxyl radical that ultimately promote the degradation of the dye molecule.

\section{Acknowledgements}

We would like to thank $\mathrm{CNPq}$ and Fapemig for financial support.

\section{References}

Nigam, P.; Armour, G.; Banat, I. M.; Singh, D.; Marchant, R.; McHale, A. P.; Mcmullan, G.; Bioresour. Technol. 2000, 72, 219.

T. Robinson, G. McMullan, R. Marchant, P. Nigam, Bioresour. Technol., 77 (2001) 247.

K. Golka, S. Kopps, Z. W. Myslak, Toxicol. Lett., 151 (2004) 203.

M. Sleiman, D. Vildozo, C. Ferronato, J. M. Chovelon, Appl. Catal., B, 77 (2007) 1.

E. Engel, H. Ulrich, R. Vasold, B. Konig, M. Landthaler, R. Süttinger, W. Baumler, R. Suttinger, W. Baumler, Dermatology, 216 (2008) 76.

F. Cicek, D. Ozer, A. Ozer, J. Hazard. Mater., 146 (2007) 408.

N. Azbar, T. Yonar, K. Kestioglu, Chemosphere, 55 (2004) 35.

O. Tunay, I. Kabdasli, G. Eremektar, D. Orhon, Water Sci. Technol., 34 (1996) 9.

T. Robinson, B. Chandran, P. Nigam, Environ. Int ., 28 (2002) 29.

C. Hachem, F. Bocquillon, O. Zahraa, M. Bouchy, Dyes Pigm., 49 (2001) 117.

M. S. Lucas, J. A. Peres, Dyes Pigm., 71 (2006) 236.

C. Galindo, P. Jacques, A. Kalt, J. Photochem. Photobiol., A , 141 (2001) 47.

J. W. Lee, S. P. Choi, R. Thiruvenkatachari, W. G. Shim, H. Moon, Dyes Pigm., 69 (2006) 196.

A. P. F. M. Urzedo, C. C. Nascentes, M. E. R. Diniz, R. R. Catharino, M. N. Eberlin, R. Augusti, Rapid Comm. Mass Spectrom., 21 (2007) 1893. 
H. Liao, D. Stenman, M. Jonsson, J. Photochem. Photobiol., A, 202 (2009) 86.

T. J. B. Holland, S. A. Redfern, Mineral. Mag., 61 (1997) 65 .

A. N. Soon, B. H. Hameed, Desalination, 269 (2011) 1.

S. Papic, N. Koprivanac, A. L. Bozic, A. Metes, Dyes Pigm., 62 (2004) 291.

N. Zaghbani, A. Hafiane, M. Dhahbi, Sep. Purif. Techonl., 55 (2007) 117.

M. A. Tarr, Chemical degradation methods for wastes and pollutants - environmental and industrial applications, Marcel Dekker: New York, 2003.

C. L. Hsueh, Y. H. Huang, C.C. Wang, C. Y. Chen, Chemosphere, 58 (2005) 1409.

R. Andreozzi, A. D'apuzzo, R. Marotta, Water Res., 36 (2002) 4691.

G. Centi, S. Perathoner, T. Torre, M. G. Verduna, Catal. Today, 55 (2000) 61.

S.Wang, Z. H. Zhu, J. Hazard. Mater., 136 (2006) 946.
T. L. P. Dantas, V. P. Mendonça, H. J. Jose, A. E. Rodrigues, R. F. P. M. Moreira, Chem. Eng. J. (Amsterdam, Neth.), 118 (2006) 77.

D. C. Menezes, G. M. de Lima, A. O. Porto, L. C. Donnici, J. D. Ardisson, A. C. Doriguetto, J. Ellena,; Polyhedron, 23 (2004) 2103.

A. G. Pereira, A. O. Porto, G. M. de Lima, H. G. L. Siebald, J. D. Ardisson, Solid State Commun., 127 (2003) 223.

M. G. Coelho, G. M. de Lima, A. O. Porto, J. D. Ardisson, Main Group Met. Chem., 28 (2005) 235. M. G. Coelho, G. M. de Lima, R. Augusti, R. D. A. Maria, J. D. Ardisson, Appl. Catal., B, 96 (2010) 67.

M. G. Coelho, G. M. de Lima, F. V. de Andrade, M. P. Ferreira, R. Augusti, D. A. Maria, J. D. Ardisson, Appl. Organomet. Chem., 25 (2011) 220.

F. V. Andrade, G. M. de Lima, R. Augusti, M. G. Coelho, J. D. Ardisson, O. B. Romero, Chem. Eng. J. (Amsterdam, Neth.), 180 (2012) 25. 